\title{
COMMUNICATION AND INFORMATION SERVICES - NATO REQUIREMENTS, PART II
}

\author{
Tibor FARKAS \\ National University of Public Service, Budapest, Hungary \\ farkas.tibor@uni-nke.hu
}

\begin{abstract}
Recent publication is the second part of an article which summing up the most important requirements, by which "Heads of State and Government of NATO member countries" have defined the basic tasks and guidelines for the alliance and the member states in order to guarantee their security. These principles and requirements fundamentally defined the needs of command and control's ICT (Information and Communication Technology) support and its management methodology. Based on these, it introduces the changes in the capabilities and requirements defined by NATO, and the general operational capabilities defining communication and information systems and services in the next 10 years after Bucharest Summit. In this paper, the author analyzes the declarations, summarizes the key directives in the field of ICT, and draws conclusions about the needs for present and future capabilities.
\end{abstract}

KEYWORDS: communication and information system, cyber defence, development, modernization, NATO Summit

\section{Introduction}

Nowadays it became focal, that NATO has to deal with constantly changing, renewing security threats, since security environment got worse greatly. The developing of defence capabilities and armed forces, as an element of international and national level reaction is required. The NATO member states began their long term defence and military development programs in the recent years by which the agility of the alliance is raised through national capabilities.

The communication and information support is one of the key elements of these modernization procedures. The new military equipments (tanks, drones, cannon) more of a computer (infocommunication) system than a weapon, and these are not only elements of the military operation, but elements of information operation and environment. To protect the information and thus our forces, the findings of the NATO Summits are the basic elements for the further research, modernization and capacity increase.

\section{NATO Summits in the Last 10 Years}

"NATO summits are not held perodically, but according to some important events of the alliance. These meetings are always organised in one of the member states and led by the Security General. [...] Decisions are summarised in resolutions, and published in the form of announcements. Afterwards the member states begin with work, by the leading of the competent organisation" (Farkas, 2020, p. 283).

By the end of the 2000s, information operations, and the protection of information networks had become increasingly important as can be seen from the declarations of the summits. 


\subsection{Strasbourg/Kehl Summit (3-4 April 2009)}

In 2009 the Alliance strenghtened their strategic concept regarding Afghanistan and Kosovo. Global threats, such as terrorist activity and the threat caused by WMD-s were defined as increasing. The peak put a focus on cyber attacks, with an emphasys on the protection of information networks.

According to the discussion, technological development has to be highlighted and maintained further, and a great awareness has to be put on information collection and the sharing of data in order to support NATO missions.

The utilisation of deployable, sustainable and agile forces has to be strenghtened, with the additional aim of avoiding possible shortcomes, thus enabling quick and efficient reaction, when needed at the place of possible crisis spots.

During the multinational operations of Afghanistan and the Balcans, NATO armed forces cooperate woth several other nations and organisations, which further stresses the importance of compatibility and interoperability in the whole spectrum of operations, regarding technical, methodical and personnel-related aspects as well.

For the sake of higher protection for the information networks of the Alliance and its members, the development of infocommunication assets has to be of highest interest, since this field also is put in the foreground on the list of recent threats. The occurance of cyber attacks is increasingly possible, against which the creation of new capabilities was urged. "To prevent and respond to such attacks, in line with our agreed Policy on Cyber Defence, we have established a NATO Cyber Defence Management Authority, improved the existing Computer Incident Response Capability, and activated the Cooperative Cyber Defence Centre of Excellence in Estonia" (NATO, 2009, p. 49). The mission of the Cooperative
Cyber Defence Centre of Excellence (CCDCOE) is to support the member nations and NATO with unique interdisciplinary expertise in the field of cyber defence research, training and exercises covering the focus areas of technology, strategy and law (CCDCOE, 2008).

One of the criteria, in order to reach the capability of high level cyber defence is that the communication and information system trainings and cyber defence trainings are buikt into NATO-s allied tranings, and that the members and partners, just like other international organisations cooperate closer in their activity against cyber attacks.

The capabilities discussed at NATO peaks have been defined according to the changes of the given era and the experience gained during activity. In my opinion, quick and effective response to the constantly evolving new threats is only possible, if we recognise the directions, which help our aims, and are able to define the principles and tools to reach our goals. This is a natural task of every NATO member states, defining the constant development greatly.

\subsection{Lisbon Summit}

\section{(19-20 November 2010)}

The summit agreed on a new strategic concept strenghtening transatlantic alliance and fostering efficient response to the new types of threats. The peak, being of high importance regarding info-communication support and cyber-defence capabilities, puts the focus on non-conventional threats and creates Emerging Security Challenges Division (ESCD).

Previous summits already have put a stress on terrorism, events threatening energy service, proliferation of WMD-s, and cyberattacks as activities destabilising security, but this was the first time, that the possible counter-measures have been collected together. Regarding new types of threats, given possible attack (such as in the 
cyber space) against one member state not necessarily has the same impact on the other members, since it cannot necessarily be regarded as being attack against NATO. Based on this, the response is also a question, since not necessarily has a military force to be deployed as answer. All these highly affect the definition of the field of collective defence. In my opinion this has created a similar situation to that after the terror events of 2001, when the type of attack, and the decision, whether the attack happened against one member only, or the whole alliance, where of question. Other feature of the new types of attacks is, that it's not always realised by a state or alliance, the actor can be any type of organisation, and that the aim is not necessarily of military nature, but possibly economical for example to destabilise the given country.

Closer cooperation is visibly more and more stronger in the field of cyber defence and information operations, also growing request for national level cyber defence capability emerged, beyond that, NATO members unite in a centralised and integrated cyber defence system.

Missile defence system became a component of this striving as a part of network capability. Tendencies show in a direction, that command, control and communication (C3) capability of the Active Layered Theatre Ballistic Missile Defence (ALTBMD) program has to be strenghtened, and expanded beyond the deployable forces also to the teritory of the European allied countries.

Although the summit puts new types of threats into focus, the alliance regards the activity against them as secondary, next to universal military tasks. It can be seen, that striwing global security cannot neglect the handling of new type threats, which thus becomes a prime feature of the Alliance's activity with a focus on critical systems (NATO, 2010).
2.3. Chicago Summit (20-21 May 2012)

New strategic concept, as defined in Lissabon comprises of three basic pillars, such as collective defence, active cooperation and crisis management. Threats have to be met as a comprehension, still with a scope on dinamic changing security environment, and with the creation of financial background. After the financial crisis, the defence budget of the nations were cut back, which makes complex security more hard to manage, thus threatening the goals set. Existing capabilites had to be maintained further as a fundament of the Alliance being able to realise complex and synchronised operations, with the need of adaptable and quickly deployable forces.To secure this, smart defence concept was created, containing a new way of thinking. The point is that the member states have to cooperate in some key features, developing capabilities together, also sharing responsibility. This way ongoing development has been secured, just as the maintaining of defence capability with efficient economic support.

Further fields of development served efficiency and ability to react, with the most important being: the renewal of command structure, rationalisation of command, reform of handling resources, and the consolidation of NATO agencies, also involving the creation of new ones, such as NATO Support and Procurement Agency (NSPA) and NATO Communications and Information Agency (NCI Agency). Latter is of key importance in the field of infocommunication support. NCI recently secures the aquisition, maintaining and protection of different communication systems at political and command level as well. It plays an important role in cyberdefence activity, the development and protection of inevitable systems, from complex systems to client assets. As a result, NATO's infocommunication support became more 
efficient, and the professional support of the member states has been broadened.

NATO is further committed in the creation of a modern, strongly connected, cooperable armed forces, provided with state-of-the-art tools and trained at high level. As an experience of the multinational operations, cooperability between national militaries has to be strenghtened, especially during common training and mission tasks. Strenghtening interoprability through the utilisation of Connected Forces Initative (CFI) is one of the pillars, connecting modern technology with education, training, preparing and evaluation. This is meant to support NATO's goals for 2020.

The further development of cyberdefence capabilities is increasingly present among the strivings, because of constant rising of cyber attacks. Defence involves the capability of prevention and detecting, with the aim of securing full spectrum allied protection in the cyber space. Cooperation with different organisations and partners is still of high importance, securing the power of common engagement. It was also announced, that by the end of the year NATO Computer Incident Response Capability (NCIRC) becomes operable, with the task of protecting the own network through providing a centralised cyber defence service, managing the events, creating reports and sharing information necessary for the broadening of defence (NATO, 2012).

\subsection{Wales Summit}

\section{(4-5 September 2014)}

"The Russian intervention against Crimea on 18.03.2014 surprised the Alliance and the whole Western world, and it wasn't prepared for the EasternUkrainean civil war either. The events in Ukraine forced the Alliance to take serious steps" (Siposné, 2017, p. 118). As a result, the high importance of collective defence in the life the alliance was announced once again, resulting in the primacy of strenghtening military capabilities among the defined goals. Two initiatives have been scheduled: Partnership Interoperability Initiative (PII) and Defence Capacity Building Initiative (DCBI). According to the situation, it became vital, that the strenghtening of the Eastern members and through it the whole Alliance becomes faster, with steps of deploying combat and technlogical assets, creating close to border bases, and develop military infrastructure.

Capability development involved supporting elements and sub-systems subserving full-spectrum military activity, characterised by interoperability in the interest of successfully utilise early warning system, allied missile defence system, or Joint Intelligence, Surveillance and Reconnaissance (JISR) system.

The volume of damage, caused by cyber attacks was again stressed, with the possible additional dangers threatening the stability of the Euroatlantic region. Cyber defence as basic task of the collective defence was again defined. It was disclosed, that every occurance will be analysed individually as being under Article 5, or not. In order of the above it was declared, that cyberdefence has to be integrated into NATO operations and planning, with the key element of information distribution, and cyber defence education and training (NATO, 2014).

\subsection{Warsaw Summit (8-9 July 2016)}

This peak can be regarded as the continuation of Wales Summit deciding the development of military capabilities.

From the Eastern neighbourhood Russia endangered the souvereighnity of the members constantly, in the South and the major cities of Europe ISIS meant a threat. Post-socialist countries and the Baltic region were dedicated towards further military strenghtening because of their geopolitical situation. In order to decrease the treats above, (four) battalion level combat groups have to be created, based on voluntary offering, being 
sustainable, working on rotational basis, being avantguard forces, which will be able to cooperate with the national forces to fulfill tasks. According to the decision made, these will be deployed by 2017 in the Baltic region and Poland. This was of relevant effect to the creation of interoperability, thus also to command and control and infocommunication support component of it. Information capabilities are further strenghtened by the cooperation with the Middle-Eastern partner Jordan in the field of Defence and Related Security Capacity Building (DCB) territory. The following seven fields were defined as being priority: information protection; cyber defence; military exercises; counter-improvised explosive devices; communication, command and control; harbour protection; and border security (NATO, 2016).

The other key element of the meeting regarding our topic was the highlighting of cyber defence tasks, regarded as inevitable element of Allied operations and planning, and agreed to be the fifth dimension of operation, next to ground, air, sea, and space. Member states repeatedly dedicated themselves for bi- and multilateral cyber defence cooperation, containing sharing of information, situation awareness, education and training.

Among universal statements was, that defence budget, supporting capabilities were increasing for the first time, also meaning the start and process of developing military technology.

\subsection{Brussels Summit (11-12 July 2018)}

Brussels didn't mean any great difference in military aspect compared to earlier decisions. The task system as described in the strategic concept, such as collective defence, crisis management, and cooperative security are definitive focusing on the unpredictable security environment. As stated earlier, the Alliance is facing threats and dangers from every strategic directions, meaning terrorist, cyber and hybrid attacks by state and nongovernmental actors and military forces.

The alliance continously maintains the tercial task system as in the strategic concept (1. collective defence, 2. crisis management, 3. cooperative security), while keeping 360 degree security approach. According to the evaluation of the peak (Announcement, Point 1.) international security environment is continously dangerous and unpredictable, NATO has to meet permanent challenges and threats from every strategic directions, meaning terrorist, cyber and hybrid attacks by state and non-governmental actors and military forces.

Decision was made, that by 2020 , 30 battalions, 30 fighter wings and 30 ships will be brought to such conditions, that they can be deployed within 30 days, and that two new commands will be established, increasing command network to 8000 personnel (NATO, 2018).

From our aspect an important change is the creation of Cyberspace Operation Center (COC), with the aim of colligating military cyber defence tasks. The goal is to make the nations develop their cyber defence (NATO, 2018).

In order to broaden defence activity spectrum, NATO has signed a common declaration with EU, launching shared tasks against collective security threats. The parties strived a quick and measurable development, containing the renewal of responding hybrid threats, strenghtening preparedness to cryses, timely information sharing on cyber attacks, and active response to desinformation (NATO, EU, 2018).

\subsection{London Summit \\ (3-4 December 2019)}

There was no real progress in the field of military questions on this anniversal meeting. An agreement was made, that the members further increase their defence budget and aquisition, share their costs and 
response for security, and take a greater roll in missions.

The agressive approach of Russia still means a threat, but the groving influence of China is also to be kept in sight. Instability beyond borders also strenghtens migration, which latter was reckoned as threat for the first time.

It was affirmed, that the survivability and security of critical infrastructure, primarily energy supply has to be strenghtened. Further, great role has to be put on the field of communication and cyber defence, in order to meet possible hybrid attacks more efficiently (NATO, 2019).

\section{Conclusions}

During any mission of NATO, on the territory of the Alliance or outside of it, on air, land or sea, be it defensive task or crisis response (See Figure no. 1), effective infocommunication support is required to make $\mathrm{C} 2$ activity successful.

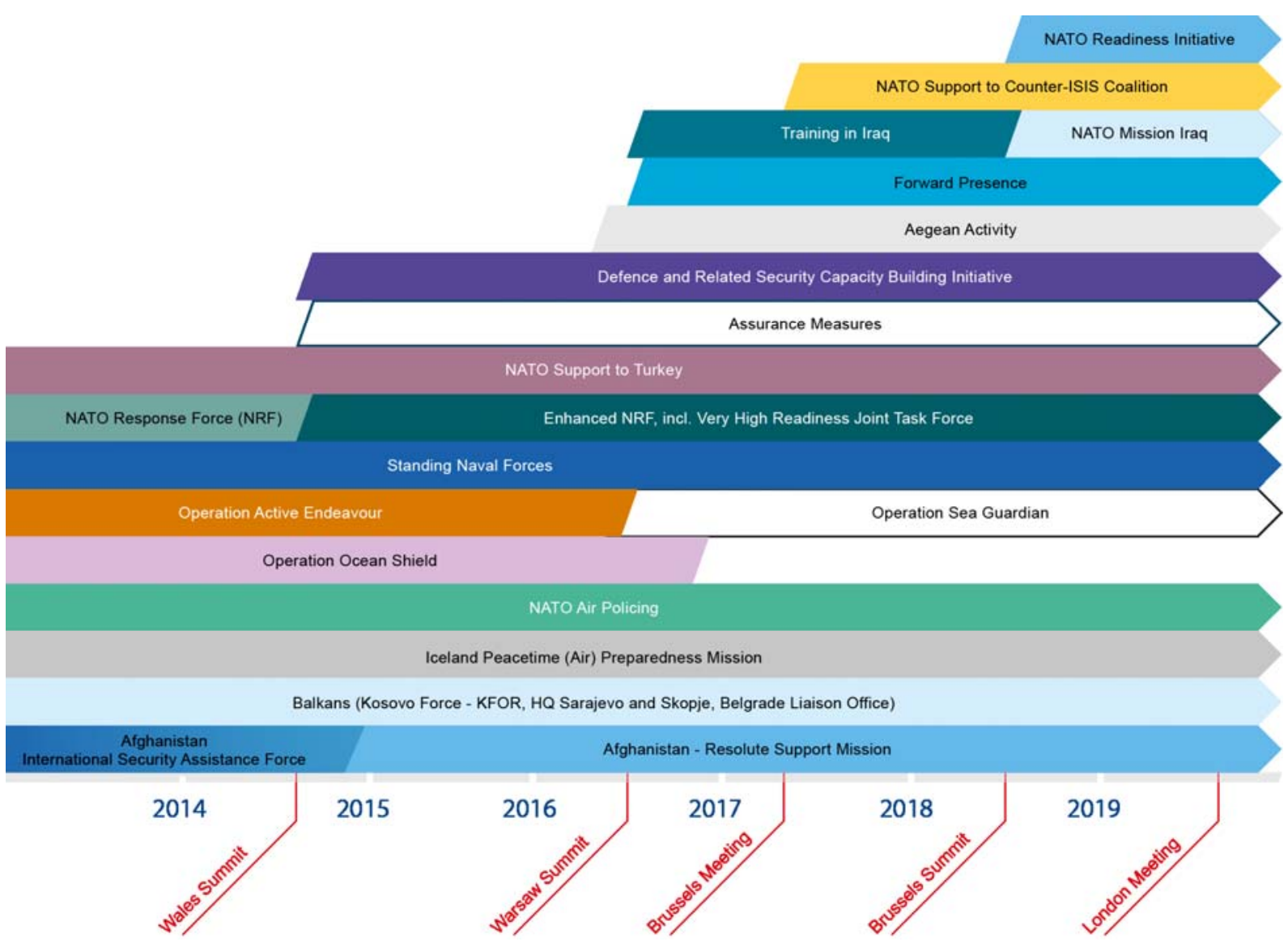

Figure no. 1: NATO Crisis Management Process

(Source: NATO, 2018, p. 15)

In the last 20 years, the approach hasn't changed, that collecting and transmitting, processing and storing, and protection of information is inevitable to reach success. A fundamental condition for this is infocommunication support, which can only be reached through high level interoperability on a common information platform. Accordingly, not the type of the given technical asset is key feature next to its capability, but the ability to be integrated to the system. 
Since a modern infocommunication system can support tasks and activity only with appropriate maintaining, the preparing and training of personnel has to be stressed, with the element of common NATO level military training being very important.

Synchronising universal operative capabilities and requirements with infocommunication support capabilities can secure the definition of infocommunication system requirements, thus the aquisition of appropriate technology and technical equipment.

\section{Acknowledgements}

This article was supported by the Ludovika - University of Public Service.

\section{REFERENCES}

Cooperative Cyber Defence Centre of Excellence (CCDCOE). (2008). Our mission \& vision, available at: https://ccdcoe.org/about-us/ accessed on 29 March 2020.

Farkas, T. (2020). Communication and information services: NATO requirements Part I. Land Forces Academy Review, Vol. 25, Issue 4, 281-289.

North Atlantic Treaty Organization (NATO) and European Union (EU). (2018). Joint declaration on EU-NATO cooperation by the president of the European Council, the president of the European Commission, and the Secretary General of the North Atlantic Treaty Organization, available at: https://www.consilium.europa.eu/media/36096/ nato eu final_eng.pdf, accessed on 11 April 2020.

North Atlantic Treaty Organization (NATO). (2009). Strasbourg / Kehl Summit Declaration, available at: https://www.nato.int/cps/en/natolive/news 52837.htm, accessed on 29 March 2020.

North Atlantic Treaty Organization (NATO). (2010). Lisbon Summit Declaration, available at: https://www.nato.int/cps/en/natolive/official_texts 68828.htm\#StratCon, accessed on 05 April 2020.

North Atlantic Treaty Organization (NATO). (2012). Chicago Summit Declaration, available at: https://www.nato.int/cps/en/natohq/official texts 87593.htm?selectedLocale=en, accessed on 10 April 2020.

North Atlantic Treaty Organization (NATO). (2014). Wales Summit Declaration, available at: https://www.nato.int/cps/en/natohq/official texts 112964.htm\#cyber, accessed on 10 April 2020.

North Atlantic Treaty Organization (NATO). (2016). Warsaw Summit Declaration, available at: https://www.nato.int/cps/en/natohq/official texts 133169.htm, accessed on 10 April 2020.

North Atlantic Treaty Organization (NATO). (2018). Brussels Summit Declaration, available at: https://www.nato.int/cps/en/natohq/official texts 156624.htm, accessed on 11 April 2020.

North Atlantic Treaty Organization (NATO). (2018). Cyber Defence Pledge, available at: https://www.nato.int/cps/en/natohq/official texts_133177.htm, accessed on 11 April 2020.

North Atlantic Treaty Organization (NATO). (2018). NATO: Ready for the future (Adapting the Alliance (2018-2019)), available at: https://www.nato.int/nato static fl2014/ assets/pdf/pdf_2019 11/20191129_191129-adaptation_2018_2019_en.pdf, accessed on 14 April 2020.

North Atlantic Treaty Organization (NATO). (2019). London Declaration, available at: https://www.nato.int/cps/en/natohq/official texts 171584.htm, accessed on 14 April 2020.

Siposné, K.K. (2017). NATO-csúcstalálkozó az elrettentés és a védelem jegyében. Hadtudomány, Vol. 27, Issue 1-2, 114-126. 